\title{
ANALISIS BUTIR TES KOMPETENSI SISTEM REM DAN SISTEM KEMUDI MATA PELAJARAN CHASSIS PADA SMK KEAHLIAN TEKNIK KENDARAAN RINGAN
}

\author{
Achmad A. Ersyad ${ }^{1}$, Wahid Munawar ${ }^{2}$, Ibnu Mubarak ${ }^{3}$ \\ Universitas Pendidikan Indonesia \\ Jl. Dr. Setiabudhi No. 229 Bandung 40154 \\ ersyad30@gmail.com
}

\begin{abstract}
ABSTRAK
Tujuan penelitian ini yaitu untuk mengetahui kualitas tes pada mata pelajaran chassis (kompetensi sistem rem dan sistem kemudi) kelas XI yang dianalisis dilihat dari validitas, daya pembeda, tingkat kesukaran, dan reliabilitas. Melalui tes yang memenuhi kualitas baik diharapkan dapat mengevaluasi pembelajaran sesuai penilaian hasil belajar yang sebenarnya. Metode penelitian yang digunakan adalah metode deskriptif pendekatan kuantitatif. Penelitian ini dilakukan di SMK Negeri di Kota Bandung dengan subyek penelitian adalah siswa kelas XI TKR berjumlah 25 siswa. Instrumen penelitian yang digunakan yaitu butir tes soal pilihan ganda. Berdasarkan hasil validitas isi dari 70 soal yang dibuat, 16 soal dinyatakan tidak valid dan 54 soal dinyatakan valid. Soal yang valid dilakukan pengujian dan pengolahan data menggunakan program komputer software ANATES V4, hasil analisis diperoleh menggunakan beberapa pertimbangan yaitu dilihat dari validitas butir soal menggunakan korelasi butir soal, daya pembeda, dan tingkat kesukaran sehingga dari beberapa pertimbangan mendapatkan simpulan 24 soal yang memenuhi kualitas baik dan koefisien reliabilitas soal memiliki nilai sebesar 0,80 berada pada kategori tinggi.
\end{abstract}

Kata kunci: kualitas tes, chassis, sistem rem, sistem kemudi

\section{PENDAHULUAN}

Meningkatkan mutu pendidikan agar berkualitas di dalamnya terdapat berbagai komponen dan program yang terencana saling berkesinambungan agar berjalan secara terartur dan terarah. Usaha dalam proses peningkatan mutu pendidikan sendiri terdapat sistem evaluasi. Sistem evaluasi merupakan salah satu bentuk dari delapan standar nasional pendidikan yang tertuang pada Peraturan Pemerintah No. 19 tahun 2005 tentang Standar Nasional Pendidikan pada Bab II Pasal 2 ayat (1) yaitu standar penilaian pendidikan yang berkaitan dengan mekanisme, prosedur, dan instrumen penilaian hasil belajar peserta didik.

Penilaian hasil belajar oleh pendidik berfungsi untuk memantau kemajuan belajar, memantau hasil belajar, dan mendeteksi kebutuhan perbaikan hasil belajar peserta didik secara berkesinambungan, sebagaimana yang dijelaskan oleh Permendikbud No. 53 Tahun 2015 penilaian hasil belajar oleh pendidik adalah proses pengumpulan informasi/data tentang capaian pembelajaran peserta didik dalam aspek sikap, aspek pengetahuan, dan aspek

\footnotetext{
1 Mahasiswa Departemen Pendidikan Teknik Mesin FPTK, UPI

2 Dosen Departemen Pendidikan Teknik Mesin FPTK, UPI

3 Dosen Departemen Pendidikan Teknik Mesin FPTK, UPI
} 
keterampilan yang dilakukan secara terencana dan sistematis yang dilakukan untuk memantau proses, kemajuan belajar, dan perbaikan hasil belajar melalui penugasan dan evaluasi hasil belajar. Kemudian lebih lanjut pada pasal 4 menjelasakan bahwa penilaian hasil belajar peserta didik didasarkan pada prinsip yaitu (a) sahih, berarti penilaian didasarkan pada data yang mencerminkan kemampuan yang diukur; (b) objektif, berarti penilaian didasarkan pada prosedur dan kriteria yang jelas; (c) adil, berarti penilaian tidak menguntungkan atau merugikan peserta didik karena berkebutuhan khusus serta perbedaan latar belakang agama, suku, budaya, adat istiadat, status sosial ekonomi, dan gender; (d) terpadu, berarti penilaian oleh pendidik merupakan salah satu komponen yang tak terpisahkan dari kegiatan pembelajaran; (e) terbuka, berarti prosedur penilaian, kriteria penilaian, dan dasar pengambilan keputusan dapat diketahui oleh pihak yang berkepentingan; (f) menyeluruh dan berkesinambungan, berarti penilaian oleh pendidik mencakup semua aspek kompetensi dengan menggunakan berbagai teknik penilaian yang sesuai, untuk memantau perkembangan kemampuan peserta didik; (g) sistematis, berarti penilaian dilakukan secara berencana dan bertahap dengan mengikuti langkah-langkah baku; (h) beracuan kriteria, berarti penilaian didasarkan pada ukuran pencapaian kompetensi yang ditetapkan; dan (i) akuntabel, berarti penilaian dapat dipertanggungjawabkan, baik dari segi teknik, prosedur, maupun hasilnya.

Permendikbud No.53 Tahun 2015 yang telah dijelaskan yaitu sistematis, artinya penilaian dilakukan secara berencana dan bertahap dengan mengikuti langkah-langkah baku. Komponen penilaian hasil belajar oleh pendidik meliputi aspek sikap (afektif), aspek pengetahuan (kognitif), dan aspek keterampilan (psikomotor). Salah satu komponen penilaian hasil belajar peserta didik oleh pendidik yaitu kompetensi pengetahuan yang diukur menggunakan suatu instrumen tes yang dapat mengukur kemampuan peserta didik pada dimensi kognitif.

Instrumen tes dalam mengukur ketercapaian keberhasilan hasil belajar pada dimensi kognitif adalah dengan melaksanakan tes berupa ujian di akhir pembelajaran. Tes adalah alat atau prosedur yang digunakan untuk mengetahui atau mengukur sesuatu dalam suasana, dengan cara dan aturan-aturan yang sudah ditentukan (Arikunto, 2016). Tes sebagai alat penilaian atau metode penilaian yang sistematis, sah, dapat dipercaya, dan objektif untuk menentukan kecakapan, keterampilan, dan tingkat pengetahuan siswa terhadap bahan ajar, berupa suatu tugas atau persoalan yang harus diselesaikan oleh seorang siswa atau sekelompok 
siswa (Basuki dan Hariyanto, 2014). Oleh karena itu, untuk mencapai harapan yang sesuai dengan rencana dan tujuan pembelajaran yang dilakukan memerlukan suatu tes yang berkualitas agar berfungsi dengan baik dan optimal serta efektif dalam mengukur ketercapaian pembelajaran yang dilaksanakan.

Ketercapaian pembelajaran agar sesuai dengan harapan dan peraturan Permendikbud No.53 Tahun 2015 yang telah dijelaskan, merupakan tugas guru sebagai pendidik yang menuntut harus mempunyai kemampuan dalam pembuatan instrumen tes penilaian evaluasi dan menganalisisnya. Berdasarkan wawancara yang telah dilakukan dengan guru di SMK Negeri 6 Bandung, pada kenyataannya terjadi ketidak sesuaian dalam pelaksanaan evaluasi pembelajaran yang dilakukan oleh guru antara lain adalah sebagai berikut: 1) Soal yang digunakan terkadang mengambil soal dari ujian nasional untuk kelas XII, 2) Soal yang dibuat guru sebelum diberikan kepada siswa belum sepenuhnya di analisis, karena guru terlalu disibukkan oleh jam mengajar yang banyak, 3) Instrumen soal yang dibuat terdapat ketidak sesuaian dalam langkah-langkah pembuatan soal yang sesuai dengan pedoman kurikulum pendidikan, 4) Instrumen soal yang dibuat belum sesuai berdasarkan dengan rencana pembelajaran dan proses belajar mengajar yang telah dilaksanakan. 5) Guru dalam membuat soal terdapat ketidak sesuaian pada materi pembelajaran sehingga soal yang digunakan belum bisa dalam mengevaluasi hasil belajar semua aspek. Sehingga instrumen tes yang dibuat oleh gurupun pada akhirnya belum sesuai atau belum efektif dalam mengevaluasi kemampuan peseta didik yang sesuai dengan kemampuan peserta didik yang sebenarnya, berdasarkan dengan pembelajaran yang diterimanya dari guru yang mengampu mata pelajaran.

\section{METODE PENELITIAN}

Metode penelitian yang digunakan yaitu deskriptif pendekatan kuantitatif. Metode ini digunakan untuk menganalisis butir tes kompetensi sistem rem dan sistem kemudi mata pelajaran chassis pada smk keahlian teknik kendaraan ringan, khususnya melalui unsur validitas, reliabilitas, tingkat kesukaran, dan daya pembeda. Tempat pelaksanaan pada penelitian ini adalah Sekolah Menengah Kejuruan (SMK) Negeri 6 Bandung. Populasi pada penelitian di SMK Negeri 6 Bandung adalah siswa kelas XI Teknik Kendaraan Ringan (TKR) berjumlah 6 kelas. Sampel pada penelitian adalah siswa kelas XI TKR 1 yang berjumlah 25 siswa. Kelas XI TKR 1 merupakan kelas T-TEP yaitu kelas kerjasama sekolah dan industri 
dimana kelas T-TEP ini kurikulum belajarnya sedikit berbeda dari kelas reguler. Pembelajaran mereka disekolah sebatas hanya sampai kelas XI, kemudian kelas XII selama setahun belajar di industri. Dengan demikian, pengetahuan mereka tentang pembelajaran kompetensi sistem rem dan kompetensi sistem kemudi yang dijadikan instrumen penelitian, sudah lebih baik daripada kelas reguler.

Instrumen penelitian yang digunakan yaitu butir tes soal pilihan ganda berjumlah 70 soal mata pelajaran chassis kelas XI yaitu meliputi kompetensi sistem rem dan kompetensi sistem kemudi yang melalui prosedur penyusunan kisi-kisi soal berdasarkan dengan kompetensi inti, kompetensi dasar, silabus, dan materi, kemudian setelah penyusunan kisi-kisi soal. Pembuatan dan penyusunan soal dilakukan berdasarkan indikator pada kisi-kisi soal yang telah disusun.

Analisis data pada penlitian ini menggunakan program komputer software ANATES V4. Software ini digunakan dengan memasukkan kunci jawaban tes dan jawaban seluruh siswa peserta tes. Lalu skor seluruh siswa peserta dan kualitas tes dapat diketahui. Pemberian skor yang dilakukan yaitu skor 1 untuk jawaban yang benar dan skor 0 untuk jawaban yang yang salah. Kualitas tes dilihat dari validitas, daya pembeda, tingkat kesukaran dan reliabilitas.

\section{HASIL PENELITIAN}

Prosedur yang dilakukan dalam penelitian ini dilakukan dengan bertahap dimulai dengan penyusunan kisi-kisi soal, pembuatan dan penyusunan soal berdasarkan kisi-kisi yang telah disusun, setelah instrumen soal dibuat dan disusun, selanjutnya dilakukan validitas isi. Validitas isi adalah validitas yang akan mengecek kecocokan di antara butir-butir tes yang dibuat dengan indikator, materi, atau tujuan pembelajaran yang ditetapkan. Butir tes dinyatakan valid, jika butir-butir yang dibuat secara tepat dapat mengukur indikator (Susetyo, 2015).

Validitas isi dilakukan oleh validator dengan menyesuaikan antara indikator pada kisi-kisi soal dengan butir soal menggunakan kriteria sesuai dan tidak sesuai. Berdasarkan hasil validitas isi diketahui bahwa dari sebanyak 70 soal yang dibuat, 16 soal dinyatakan tidak valid dan 54 soal dinyatakan valid. 54 Soal yang valid dilakukan pengujian kepada siswa terlebih dahulu dan kemudian hasil pengujian diolah data menggunakan program komputer software ANATES V4. Hasil analisis menggunakan beberapa pertimbangan dilihat dari validitas butir soal menggunakan korelasi butir soal. Soal dikatakan signifikan ketika r hitung 
$\geq 0,250$ sesuai dengan info batas signifikansi maka didapatkan hasil yaitu 25 soal dinyatakan signifikan dan 29 soal dinyatakan tidak signifikan. Hasil analisis daya pembeda dengan menggunakan ketentuan kriteria didapatkan hasil yaitu 18 soal berkriteria sangat buruk, 11 soal berkriteria buruk, 5 soal berktriteria agak baik, 7 soal berkriteria baik, dan 13 soal berkriteria sangat baik. Hasil analisis tingkat kesukaran dengan menggunakan ketentuan kriteria didapatkan hasil yaitu 4 soal berkriteria sangat sukar, 7 soal berkriteria sukar, 34 soal berkriteria sedang, 4 soal berkriteria mudah, dan 5 soal berkriteria sangat mudah.

Hasil analisis pengambilan simpulan terhadap kualitas butir-butir tes sesuai dengan mengungkapkan bahwa apabila dua dari tiga kriteria butir tes yang baik dapat terpenuhi atau konsisten, maka butir tes tersebut dapat digunakan. Sebaliknya apabila dua dari tiga butir kriteria butir tidak dapat memenuhi kualitas butir yang baik maka butir tes perlu diganti atau direvisi (Mulyatiningsih, 2013). Kemudian berdasarkan pengambilan kesimpulan menunjukkan bahwa dari soal yang valid didapatkan 30 soal tidak dapat memenuhi kualitas baik. Soal tersebut diganti atau direvisi untuk digunakan dan 24 soal yang memenuhi kualitas baik sehingga layak digunakan. Didapatkan pula koefisien reliabilitas soal memiliki nilai sebesar 0,80 berada pada kategori tinggi.

\section{PEMBAHASAN}

Pada pengujian validitas diuji melalui dua cara yaitu dengan validitas rasional dan validitas empirik. Secara rasional, validitas butir soal dilihat dari kesesuaian butir soal dengan indikatornya. Berdasarkan hasil yang telah di analisis oleh validator terdapat sebanyak 16 soal tidak valid yang tidak sesuai butir soal dengan indikator yang dibuat dan disusun dari 70 soal yang dibuat. 54 Soal yang valid kemudian diujikan kepada siswa yang telah ditentukan sebagai objek penelitian di sekolah, setelah diujikan kepada siswa kemudian langkah selanjutnya dilakukan validitas secara empirik atau butir soal (item).

Analisis validitas butir soal merupakan kegiatan analisis yang bertujuan untuk mengetahui keakuratan suatu tes dalam menjalankan fungsinya, dalam analisis ini menggunakan program komputer software ANATES V4 dengan teknik korelasi. Hasil analisis

validitas butir soal yang telah dilakukan dapat disimpulkan berdasarkan hasil penelitian memiliki 29 soal yang tidak dapat menjalankan fungsi ukurnya dengan baik karena tidak signifikan dan 25 soal yang dapat menjalankan fungsinya dengan baik karena signifikan. 
Analisis daya pembeda merupakan kegiatan analisis yang bertujuan untuk mengetahui kesanggupan soal untuk membedakan siswa yang sudah menguasai kompetensi dan yang belum menguasai kompentensi. Perhitungan analisis daya pembeda ini menggunakan program komputer software ANATES V4. Hasil analisis daya pembeda butir soal yang telah dilakukan dapat disimpulkan berdasarkan hasil penelitian kemampuan soal membedakan siswa yang sudah menguasai kompetensi dan yang belum menguasai kompetensi masih dalam kategori cukup.

Analisis tingkat kesukaran merupakan kegiatan analisis yang bertujuan untuk mengetahui kualitas tingkat kesukaran pada butir soal. Butir soal yang mana sangat mudah yang tidak merangsang siswa untuk mempertinggi usaha memecahkannya dengan baik, sedangkan butir soal mana yang sangat sukar yang merangsang siswa untuk mempertinggi usaha memecahkannya dengan baik sehingga menyebabkan siswa putus ada dan tidak mempunyai semangat untuk mencoba kembali. Butir soal tes sebaiknya menggunakan butir soal yang tingkat kesukarannya berimbang atau sama, yaitu sukar $=25 \%$, sedang $=50 \%$, dan mudah $=25 \%$ (Widoyoko, 2014). Hasil analisis tingkat kesukaran butir soal yang telah dilakukan dapat disimpulkan berdasarkan hasil penelitian kualitas tingkat kesukaran sudah baik, karena banyaknya soal berkriteria sedang.

Pada pengambilan simpulan dengan menggunakan beberapa pertimbangan hasil analisis hasil analisis tingkat kesukaran (TK), daya pembeda (D), dan korelasi (r) butir (validitas butir soal) yang telah dilakukan sebanyak 30 soal tidak dapat memenuhi kualitas butir yang baik, butir soal perlu diganti atau direvisi untuk digunakan lebih lanjut dan 24 soal memenuhi kualitas butir yang baik maka diterima sehingga layak digunakan.

Analisis reliabilitas merupakan analisis yang bertujuan untuk mengetahui seberapa tetap, dipercaya atau ajeg suatu tes dalam menilai apa yang dinilainya. Perhitungan analisis reliabilitas ini juga menggunakan program komputer software ANATES V4. Hasil analisis reliabilitas ini hanya menganalisis pada soal yang memenuhi kualitas baik dan diterima saja. Analisis reliabilitas ini hanya untuk menyempurnakan dan meyakinkan bahwa kualitas butir soal yang telah di analisis pada tahap sebelumnya memang telah benar-benar memiliki kualitas yang dapat dipakai dalam mengevaluasi hasil belajar. Berdasarkan pengujian memiliki koefisien reliabilitas sebesar 0,80 , nilai kriteria 0,80 berdasarkan tabel koefisien reliabilitas teletak pada kriteria tinggi sehingga soal tersebut dapat dikatakan reliabel dan dapat dipercaya. 


\section{KESIMPULAN}

Kesimpulan penelitian ini, sebagai berikut: analisis butir tes kompetensi sistem rem dan sistem kemudi mata pelajaran chassis soal bentuk pilihan ganda sebanyak 70 soal, dianalisis dilihat dari validitas isi dapat diketahui $22,85 \%$ soal tidak valid dan tidak sesuai antara butir soal dengan indikator soal dan 77,14\% soal valid sesuai antara butir soal dengan indikator soal. Hasil uji menunjukkan 25 soal dinyatakan signifikan dan 29 soal dinyatakan tidak signifikan. Daya pembeda didapatkan hasil kualitas butir soal sesuai dengan kriteria bahwa 18 soal dinyatakan sangat buruk, 11 soal dinyatakan buruk, 5 soal dinyatakan agak baik, 7 soal dinyatakan baik, dan 13 soal dinyatakan sangat baik. Tingkat kesukaran didapatkan hasil kualitas butir soal sesuai dengan kriteria bahwa 4 soal dinyatakan sangat sukar, 7 soal dinyatakan sukar, 34 soal dinyatakan sedang, 4 soal dinyatakan mudah, dan 5 soal dinyatakan sangat mudah. Terakhir kualitas butir soal yang memenuhi kualitas butir yang baik dilihat dari keofisien reliabilitas memiliki nilai sebesar 0,80. Berdasarkan kriteria reliabilitas instrumen nilai reliabilitas 0,80 terletak dikriteria tinggi, sehingga dapat dikatakan bahwa soal reliabel dan dapat dipercaya.

\section{REFERENSI}

Arikunto, S. (2016). Dasar-Dasar Evaluasi Pendidikan. (edisi kedua) Jakarta: PT Bumi Aksara.

Basuki, I. \& Hariyanto (2014). Asesmen Pembelajaran. Bandung: PT Remaja Rosdakarya.

Mulyatiningsih, E. (2013). Metode Penelitian Terapan Bidang Pendidikan. Bandung: Alfabeta.

Peraturan Menteri Pendidikan dan Kebudayaan Republik Indonesia No. 53 Tahun 2015 tentang Penilaian Hasil Belajar Oleh Pendidik Dan Satuan Pendidikan Pada Pendidikan Dasar Dan Pendidikan Menengah. Jakarta: Kementerian Pendidikan dan Kebudayaan.

Susetyo, B. (2015). Prosedur Penyusunan \& Analisis Tes untuk Penilaian Hasil Belajar Bidang Kognitif. Bandung: PT Refika Aditama.

Widoyoko, E. P. (2014). Penilaian Hasil Pembelajaran di Sekolah. Yogyakarta: Pustaka Pelajar. 